DOI: https://doi.org/10.32839/2304-5809/2021-5-93-20

УДК 323:1

Скрипченко I.B.

Київський національний університет імені Тараса Шевченка

\title{
ГРОМАДСЬКО-ПОЛІТИЧНИЙ РУХ «ВLAСК LIVES MATTER» ТА ЙОГО РОЛЬ В ЗРОСТАННІ НАСИЛЛЯ ПРОТИ АФРОАМЕРИКАНЦІВ В США
}

\begin{abstract}
Анотація. В статті досліджуеться громадсько-політичний рух «Black Lives Matter» та його роль в зростанні насилля проти афроамериканщів в США. «Black Lives Matter» є сьогодні найбільш відомим та масовим в рухом в Сполучених Штатах. 3 часу появи руху в 2013 році, організатори проголосили, що його метою є збереження життя афроамериканців та зменшення рівня насилля щодо них. Також організатори руху наголошували на існування в США інституційного расизму. Різкий сплеск насилля в Сполучених Штатах було зафіксовано в 2014-2016 роках. В цей час відбулося багато насильницьких злочинів на расовому тлі. Причиною такого розвитку подій були агресивні дії активістів «Black Lives Matter» під час протестів у багатьох містах США. Ці протести переростали в масові погроми та пограбування. В статті наведено низку досліджень державних та недержавних установ Сполучених Штатів. Вони демонструють, що рівень смертності серед афроамериканців почав збільшуватися після 2014 року. В ході дослідження виявлено, що масові погроми в низці американських міст викликали значне зростання злочинності. В статті встановлено, що вбивства в США носять внутрішньорасовий характер. Тому різке підвищення рівня злочинності викликало й підвищення рівня смертності серед афроамериканців. Також виявлено, що поліцейські не діють упереджено до афроамериканців. Антиполіцейська риторика організаторів та активістів руху «Black Lives Matter» призвела навпаки до зменшення активності поліцейських в районах щільного проживання афроамериканців. Цей феномен отримав назву «Ефект Фергюсона». Встановлено, що від цього смертність афроамериканців упродовж 2014-2016 значно збільшилась. Отже, діяльність Громадсько-політичного pyху «Black Lives Matter» тільки дестабілізувало становище в США та погіршило становище афроамериканської спільноти.
\end{abstract}

Ключові слова: громадсько-політичний pyx «Black Lives Matter», BLM, Алісія Гарза, Патріс Каллорс, поліція, ФБР, США, насилля, «Ефект Фергюсона».

Skrypchenko Ihor

Taras Shevchenko National University of Kyiv

\section{THE POLITICAL AND SOCIAL MOVMENT BLACK LIVES MATTER AND ITS ROLE IN THE GROWTH OF VIOLENCE AGAINST AFRICAN AMERICANS IN THE UNITED STATES}

Summary. The article examines the role of the socio-political movement Black Lives Matter in the beginning of the escalation of violence in American society. Black Lives Matter is the most famous and popular movement in the United States nowadays. Since the movement's inception in 2013, organizers have stated that its goal is to save the lives of African Americans and reduce violence against them. The movement's activists also stressed the existence of institutional racism in the United States. According to the leaders of the movement Alicia Garza, Patrisse Cullors and Opal Tometi, law enforcement agencies are to blame for the high mortality rate among African Americans. A sharp surge in violence was recorded in the United States in 2014-2016. There were many racially motivated violent offences during that time. The reasons for such a development include aggressive actions of Black Lives Matter activists during the protests in many US cities. The protests escalated into mass riots and looting. The activities of the Black Lives Matter have led to an increase in political polarization in the United States, while the aggressive actions of the protesters made many extremists and ordinary people commit racists crimes. The article presents a number of studies of governmental and non-governmental institutions of the United States. The studies show that the death rate among African Americans began to increase after 2014. The article found that the mass riots in a number of US cities had caused a significant increase in crime. The article also found that the killings in the United States were of an interracial nature. Therefore, the sharp rise in crime has caused an increase in the mortality rate among African Americans. Police were not found to be biased against African Americans. On the other hand, the anti-police rhetoric of the organizers and activists of the Black Lives Matter movement, has reduced police activity in densely populated areas of African Americans. This phenomenon is called the «Ferguson effect». It has been found that such a fact significantly increased the death rate among African Americans during 2014-2016. Thus, the activities of the socio-political movement Black Lives Matter only destabilized the situation in the United States and worsened the situation in the African-American community.

Keywords: socio-political movement Black Lives Matter, BLM, Alicia Garza, Patrisse Cullors, police, FBI, USA, violence, «Ferguson effect».

Постановка проблеми. 32014 року в Сполучених Штатах відбуваеться зростання політичної поляризації в суспільстві. Причиною цьому стали масові протести та погроми, які відбувалися в 2014-2015 роках у низці американських міст. Головними організатором цих протестів був громадсько-політичний pyx «Black
Lives Matter». Саме його діяльність призвела до ескалації насилля в США. Внаслідок антиполіцейської агітації активістів руху поліція почала менше приділяти уваги громадській безпеці. Це викликало зростання рівня злочинності. Високий рівень злочинності та постійні масові погроми збільшили смертність у афроамерикан- 
ській громаді. Тож важливо визначити причини такого перебігу подій та роль руху «Black Lives Matter» в погіршені безпекової ситуації в США. Також, дослідження допоможе краще зрозуміти причини та наслідки масових протестів та погромів, які відбувалися влітку 2020 року в Сполучених Штатах.

Аналіз останніх досліджень і публікацій. В досліджені проаналізовані матеріали державних та недержавних інститутів США. Зокрема проаналізовано та систематизовано дані Федерального бюро розслідувань США та Центрів по контролю та профрілактиці захворювань в США. В статі наводяться матеріали та публікації американських дослідників Д.М. Клейтона, Ш. Джонс-Еверслі, Дж. Райса, А.К. Адедойна, Л. Джеймс-Таунс, Х. Макдональд, Л. Елдера, М. Гудвіна, Е. Дей, Р. Лавлейса, Дж. Солтера, Д.Л. Мура. Також в дослідженні наводяться публікації та висловлювання організаторів громадсько-політичного руху «Black Lives Matter».

Виділення не вирішених раніше частин загальної проблеми. Дослідження ролі громадсько-політичного руху «Black Lives Matter» в зростанні насилля проти афрроамериканської громади в США дозволяе виявити справжні цілі, якими керувались організатори руху при його створені, що дозволяе зрозуміти причини збільшення рівня насильства у США в 2014-2015 роках та зрозуміти їх вплив на протести в США в 2020 році.

Мета дослідження. Визначити та дослідити громадсько-політичний рух «Black Lives Matter» та його роль в зростанні насилля проти афрроамериканців в США.

Виклад основного матеріалу. «Black Lives Matter»(3 англ. - «Життя темношкірих мають значення») - громадсько-політичний рух в США, який виступає проти упередженого насилля по відношенню до афрроамериканців. Профресор політології Луїсвільського університету Дьюї М. Клейтон визначає, що ціллю руху є ліквідація расової несправедливості, яка пронизує і охоплює різні сфери суспільства $[7$, с. 2]. На сайті самого руху також зазначається, що ціллю BLM $€$ «викорінення білого панування» та «створення локальних сил» для запобігання насиллю по відношенню до афрроамериканців зі сторони держави та недержавних організацій, а також створення простору можливостей для вільної діяльності афрроамериканської спільноти в США [2].

Громадсько-політичний pyx «Black Lives Matter» виник у липні 2013 року. Його організатори Алісія Гарза, Патріс Каллорс та Опала Тометі організовували масові протести, використовуючи в сощіальних мережах хештег \#blacklivesmatter. Найбільш організовані масові акції протесту відбувалися в 2014-2015 роках, а також в 2020 році. Причиною протестів були смерті афрроамериканців від рук поліцейських. Найбільш гучними були справи щодо смерті adpроамериканців Трейвона Мартіна, Майкла Брауна та Еріка Гарнера в 2013-2014 роках. Організатори та активісти руху вважали, що ці смерті були пов'язані з існуванням в США системного расизму по відношенню до афроамериканців. Крім того, учасники руху зазначали, що судова система в США є расово упереджена. Цей фракт, на їх погляд, тільки погіршував становище зі смертністю серед темношкірого населення в Сполучених Штатах [7, с. 2-3].

Однак, розслідування поліції та ФБР виявили повну відсутність расових упереджень по всіх справах. Кількість доказів, які про це свідчили, було більше ніж достатньо, що не залишає можливості у подвійному трактуванні цих справ. Тому заяви організаторів та активістів BLM виглядали як навмисне проведення маніпуляцій на расовому тлі, що призводило до масових протестів, які в більшості випадків переростали в погроми та пограбування. Крім того, результатом цих протестів стало збільшення вбивств серед темношкірого населення, а також загальне збільшення насильства в США [1].

Після смерті афроамериканця Майкла Брауна в місті Фергюсон, штат Miссурі, 9 серпня 2014 року почалися локальні масові протести, які майже одразу переросли в масові пограбування та погроми [12]. Приїзд до Фергюсону 500 активістів із різних штатів на чолі з організаторами руху А. Гарзою, П. Каллорс та О. Тометі тільки дестабілізували ситуацію. Патріс Каллорс порівнювала смерть М. Брауна зі сценами лінчування темношкірих, які відбувалися століття назад [10]. Такі порівняння тільки підбурювали агресивних протестувальників. Внаслідок суспільних безладів у Фергюсон була введена національна гвардія. Через погроми та пограбування, які супроводжували протести, деякі крамниці та магазини встигли зазнати вандалізму декілька разів підряд. Поки тривало розслідування місцевої поліції та ФБР, у Фергюсоні час від часу продовжували спалахували протести. Внаслідок нагнітання активістами ситуації, будь-які дії правоохоронців викликали обурення аdpоамериканської громади.

Ще більші погроми відбулися у місті через 3 місяці, після оголошення Великим журі присяжних округу Сент-Луїс свого рішення не висувати звинувачень поліцейському Даррену Вільсону, якого підозрювали у навмисному вбивстві Брауна. У нових масових хвилюваннях приймали участь і активісти BLM, які блокували місцевий торговий центр та підбурювали до агресивних дій проти правоохоронців. Одна із засновниць BLM Патріс Каллорс закликала зробити 2015 рік - «роком некерованості» [11]. Довго чекати не довелось. Начальник поліції округу Сент-Луїс Джон Белмар в ніч після прийняття рішення присяжних заявив, що він особисто нарахував до 150 пострілів у місті [23]! Через таку ситуацію Федеральне авіаційне управління США змушено було направити частину авіарейсів 3 Сент-Луїса до інших аеропортів через загрозу їх безпеки. Крім того, ще в серпні авіаційне управління заборонило на 2 тижні польоти літаків та вертольотів в межах 37 квадратних миль, через постійні перестрілки, які відбувалися у Фергюсоні та околицях [26].

Тодішній президент США Барак Обама, peагуючі на погроми, закликав протестувальників відмовитися від насильства. Він додав, що не має співчуття до тих, хто використовуе рішення присяжних як виправдання для здійснення насильства [3]. Обама також зазначив, що протестувальники мають змиритися із рішенням присяжних: 
«Ми маємо сприйняти це рішення Великого журі» [18]. За декілька годин до оприлюднення рішення присяжних, губернатор штату Міссурі оголосив, що надішле до округу Сент-Луїс додаткові сили для підтримання правопорядку у випадку суспільних протестів. Але в реальності, всі ці заяви не мали ніякого впливу на ті жахливі наслідки, які відбувалися у Фергюсоні та околицях. Все місто підсвічувалося вогнищем від пожеж. Рятувальні та пожежні служби не могли виконувати свої обов'язки, оскільки могли бути піддані небезпещі внаслідок постійної стрілянини в місті. Були розграбовані та спалені десятки магазинів та навіть фрастфудів [19].

Політичний оглядач «New York Post» Майкл Гудвін звинувачуе в такому розвитку подій поліцію та національну гвардію, які не протидіяли масовим безладам. В той же час, бездіяльність правоохоронців він пов'язуе з позицією політичного керівництва в країні, яке недостатньо засудило протести та не підтримали публічно поліцію [19]. Фактично, політичне керівництво США, як на місцевому рівні, так і на вищому, піддалося нав'язаному дискурсу активістів BLM стосовно існування проявів системного расизму серед працівників поліції.

Крім того, в погромах в окрузі Сент-Луїс активісти BLM та більшість 3MI звинувачувала вердикт присяжних. Мовляв, Велике журі спровокувало людей, бо винесло рішення на яке вони не розраховували [19]. Організатори «Black Lives Matter» заявляли, що adpоамериканська громада живе начебто у страху через дії правоохоронців. Насправді ж, після постійних погромів та перестрілок в окрузі Сент-Луїс та інших містах, почуття страху за своє життя серед мешканців стало тільки більше [22]. Такі наслідки стали можливими тільки завдяки свідомій маніпуляції фоктами організаторами та активістами BLM.

Смерть афроамериканця Еріка Гарненра 17 липня 2014 року під час затримання в НьюЙорку, також викликала резонанс серед афроамериканської громади і переросла у масові протести. Останні слова Гарнера «Я не можу дихати» стало гаслом, яке скандували активісти BLM під час протестів проти поліції [12]. Але радикальне зростання насилля відбулося після винесення 3 грудня того ж року рішення Великого журі присяжних, яке відмовилося висувати звинувачення поліцейським. Тільки за перші декілька днів заворушень було заарештовано близько 300 людей, яким інкримінували статті за напад на поліцейських та хуліганство [20].

Під час великої демонстрації в Нью-Йорку, яка пройшла через тиждень після рішення Великого журі і зібрала до 30000 людей, сутичок з поліцейськими уникнути не вдалось. Окремі демонстранти нападали на поліцейських, внаслідок чого двоє лейтенантів поліщії були ушпиталені [17]. Крім гасел «Black Lives Matter» та «Я не можу дихати» протестувальники скандували: «Чого ми хочемо? Смерті копів! Коли ми цього хочемо? Негайно!» [29]. На жаль, ці заклики були згодом втілені у життя. В помсту за вбивство Гарнера та Брауна 20 грудня 2014 року в Нью-Йорку були розстріляні у поліцейській машині двоє правоохоронців. Вбивцею виявився афроамериканець Ісмаїл Абдулах Брінслі, який за декілька годин до стрілянини зробив запис в соціальній мережі «Instagram» зі словами: "Сьогодні я накину свиням крила ... Вони забрали одного з наших ... Давайте заберемо двох їхніх» [6].

В цей момент Америка виявилася, фрактично, в умовах початку нової хвилі насильства на расовому тлі. Кожен стрілок вважав, що його помста справедлива і виправдовував свої злочини моральним принципом «око за око». Однак, всі ці злочини були наслідками масових протестів BLM проти поліцейських, яких вони звинувачували в інституційному расизмі. Організатори та активісти "Black Lives Matter» постійно вказували на колір шкіри поліцейських, нав'язуючи расистський дискурс. Вони нав'язували думку, що білі американці - єдині хто винен у смертях всіх афроамериканців.

Своїми насильницькими діями громадсько-політичний pyx «Black Lives Matter» не просто спровокував збільшення поляризації в суспільстві на расовому тлі. Він спровокував значне зростання насильства. I найбільшими жертвами цього насильства були саме афрроамериканщі, за права яких, начебто, і борються активісти BLM. Дослідники Ш. Джонс-Еверслі, Дж. Райс, А.К. Адедойн та Л. Джеймс-Таунс виявили погану тенденцію щодо смертності від вбивств молодих афроамериканців віком від 15 до 24 років. Кількість вбивств $€$ надзвичайно високою, особливо у порівнянні 3 іншими расовими групами в США [21, с. 256]. Так, згідно статистики Центрів по контролю та профрілактиці захворювань в США, в період 3 1970-х років відбувалося збільшення кількості вбивств серед молодих афрроамериканщів [13]. На 100.000 осіб населення цей показник виріс з 43,2 в 1960 році до 71 в 2010 рощі. При цьому максимальний пік вбивств був у 1990 році і складав в середньому 137,1, після чого їх кількість стабільно зменшувалась. Крім того, статистика щодо вбивств афроамериканців є загрозливо великою не тільки серед молоді. В 2010 році, на 100.000 населення кількість смертей через вбивство серед темношкірих чоловіків віком від 25 до 44 років складала 55,9. Для порівняння, середня кількість вбитих білих чоловіків того ж віку в 2010 році складала - 6,9, а серед чоловіків віком від 15 до 24 років - 8,2 [13]. Дослідники, як i активісти BLM, вважають, що така статистика вбивств пов'язана, в тому числі, через інституційний расизм державних органів США, зокрема і правоохоронних органів [21, с. 262]. Але автори суперечать самі собі, оскільки кількість вбивств за часів існування сегрегації та формальних расових законів була нижчою. Тож навряд чи причиною такої кількості вбивств є інститущійний расизм.

Внаслідок пропаганди ворожнечі, яку посіяли організатори та активісти руху «Black Lives Matter» рівень насильства та вбивств у США тільки збільшився. За даними ФБР, в 2015 році кількість тяжких злочинів на 100.000 осіб зросла на $3,1 \%$ порівняно з рівнем 2014 року. Загальна кількість вбивств в країні збільшилась майже на $11 \%$, кількість згвалтувань на 6,3\%, нападів при обтяжуючих обставинах на $4,6 \%$, а загальна кількість тяжких злочинів в країні зросла на 3,9\%, порівнюючи з 2014 роком, тим самим порушивши тенденцію попередніх двох років, згідно з якою рівень злочинів стабільно знижувався [16]. Дан- 
Кількість вбивств темношкірих чоловіків в США

Таблиця 1 на 100.000 населення з 1950 по 2016 рр. [13; 14]

\begin{tabular}{|c|c|c|c|c|c|c|c|c|c|c|}
\hline \multirow{2}{*}{ Вік чоловіків } & \multicolumn{10}{|c|}{ Piк } \\
\cline { 2 - 26 } & $\mathbf{1 9 5 0}$ & $\mathbf{1 9 6 0}$ & $\mathbf{1 9 7 0}$ & $\mathbf{1 9 8 0}$ & $\mathbf{1 9 9 0}$ & $\mathbf{2 0 0 0}$ & $\mathbf{2 0 1 0}$ & $\mathbf{2 0 1 4}$ & $\mathbf{2 0 1 5}$ & $\mathbf{2 0 1 6}$ \\
\hline $15-24$ & 53,8 & 43,2 & 98,3 & 82,6 & 137,1 & 85,3 & 71 & 65 & 74,9 & 85,5 \\
\hline $25-44$ & 92,8 & 80,5 & 140,2 & 130 & 105,4 & 55,8 & 55,9 & 54,8 & 65,5 \\
\hline
\end{tabular}

ні ФБР підтверджуються даними Центрів по контролю та профілактиці захворювань в США. В 2014 році, на 100.000 осіб кількість вбитих афроамериканських чоловіків віком від 15 до 24 років складала в середньому 65, а вже в 2015 цей показник зріс до 74,9. В 2016 ця негативна тенденція продовжилася і складала вже відмітку у 81,4. Серед афрроамериканських чоловіків віком від 25 до 44 років середня кількість вбивств складала 54,8 в 2014 році, а вже в 2015 році ця кількість зросла до 65,5. В 2016 році ця цифра сягала відмітки в 70,4 [14].

Активісти BLM постійно повторюють тезу про те, що американські поліцейські цілеспрямовано «винищують» афроамериканську спільноту. Одна із організаторів «Black Lives Matter» Патріс Каллорс зазначала: «Громади були спустошені. Покоління людей отримали травми. Це національний терор. А насилля проти темношкірих зі сторони правоохоронних органів продовжуеться й досі» [11]. Але гучні заяви активістів ВLM одразу розсипаються, зіштовхнувсь з реальністю. Криміналістична статистика повністю спростовуе нав'язаний дискурс про інституційний расизм. Згідно незалежних підрахунків журналістів «The Washington Post» в 2015 році поліцейські вбили 987 людей. Серед них білі американці складали 50\%, а темношкірі лише 26\% $[24$, c. 79]. В попередні роки ця статистика також не відрізнялась. Згідно даних Центрів по контролю та профілактиці захворювань в США з 1999 по 2013 рік поліція вбила 3160 білих американців і 1724 темношкірих [15]. Якщо хто i може стверджувати про упереджене ставлення поліції, так це білі американці.

Однак, треба враховувати, що білі американці складають майже 65\% населення США, а темношкірі американці - лише 13\%. Але, білі американці скоюють набагато менше тяжких злочинів - лише 10\% від всього населення в США [15]. В свою чергу, афроамериканщі здійснюють непропорційно велику кількість вбивств та інших тяжких злочинів. Тільки в 2009 році, афроамериканці були обвинувачені в $57 \%$ від всіх вбивств, в $62 \%$ всіх пограбувань, в 45\% всіх нападів здійснених в 75 найбільших округах США, де афрроамериканці складала лише приблизно 15\% населення [24, с. 79]. Згідно статистики ФБР, з усіх ідентифікованих вбивць в 2015 році - 53,3\% були афрроамериканцями, і тільки 44\% виявилися білими [9]. Крім того, згідно звіту Національного інституту юстищіі, проведеного в 2013 рощі, 75\% aфpoамериканців визнавали, що поліцейські зупиняли їх для перевірки на законних підставах [15].

Основними вбивцями афроамериканців є не білі поліцейські, а злочинці, у яких також темний колір шкіри. Так, ще в 2000 році, за даними ФБР, вбивства у США носили внутрішньорасо- вий характер. 93,7\% від загальної кількості вбитих афроамериканців, були вбиті темношкірими злочинцями, а $86,2 \%$ білих американців були вбиті злочинцями із білим кольором шкіри [8]. Така ж тенденція продовжувала існувати й в наступні роки. Так, згідно статистичних даних ФБР за 2015 рік, з 3,167 білих американців вбитих у 2015 році, 2,574 людини були вбиті злочинцями у яких був білий колір шкіри і тільки 500 було вбито афроамериканцями. А з 2,664 вбитих афрроамериканців, 2,380 були вбиті темношкірими злочинцями і тільки 229 було вбито злочинцями із білим кольором шкіри [25]. Центр з питань дослідження проявів насильства зазначае, що 75\% афроамериканців, які були вбиті в 2015 рощі, були раніше знайомі зі своїми вбивцями [4, с. 2]. Ця статистика тільки підтверджує дані ФБР про внутрішньорасовий характер вбивств у США. Організатори BLM критикують поліцію за те, що з 2,3 мільйонів ув'язнених станом на 2015 рік, майже 1 мільйон складали афроамериканці [12]. Але згідно статистичних даних ми бачимо, що серед них більшість своїми злочинами приносила шкоду саме афроамериканській спільноті.

Зростання кількості вбивств афроамериканців після 2014 року було пов'язано зі зменшенням активності дій поліції. Комісар поліції округу Сент-Луїс Сем Дотсон назвав цю негативну тенденцію «Ефектом Фергюсона». Через масову критику від політиків та 3MI, поліцейські перестали діяти на випередження злочинів і почали все частіше пращювати у ролі «статистів», лише реагуючи на вже здійснені. 3 літа до листопада 2014 року кількість арештів у Фергюсоні та окрузі Сент-Луїс зменшилася на третину. Такий стан справ зіграв тільки на руку злочинцям і кількість вбивств за той же період збільшилася на 47\%, а кількість пограбувань на $82 \%$ [24, с. 64-65]. 3 серпня 2014 по серпень 2015 року кількість вбивств у містах США зросла на небачені до цього показники. В Мілуокі кількість вбивств збільшилась на 76\%, в Сент-Луїсі на 60\%, в Балтиморі на $56 \%$, в Міннеаполісі на $47 \%$ і на $36 \%$ в Хьюстоні. Настільки різке зростання злочинності стало причиною екстреного скликання "Асоціації мерів великих міст» в серпні 2015 року [24, с. 72$]$.

В 2019 рощі мер Фергюсона Джеймс Ноулз відзначав велику проблему з нестачею поліцейських: «Є багато людей, особливо 3 найкращих та найбільш підходящих для поліції, які задають собі питання: «Чи я хочу пройти через все це і змусити свою сім'ю пройти через все це?» [27]. Такі питання собі задають всі американські правоохоронці, згадуючи численні погрози фрізичної розправи поліцейському Даррену Вільсону та його сім'ї від послідовників «Black Lives Matter». Mep Фергюсона вважає, що злочинщі стали більш нахабними, знаючи, що поліція не наважується ді- 
яти рішуче для їх зупинення. «Якщо ви не зупиняєте та не перевіряете людей, ви не прибираєте цю зброю з вулиць, ви не вилучаєте контрабанду та незаконну зброю», - зазначав Дж. Ноулз [27].

Від збільшення злочинності в США найбільше доводиться розплачуватися саме афроамериканцям. В 2015 році тільки в Каліфрорнії 50\% афрроамериканців були вбиті через діяльність кримінальних банд [4, с. 2]. Голова Департаменту шеридра округу Лос-Анджелес Джим Макдоннелл, реагуючи на події 2014-2015 року, зазначав, що ворожість та упередженість до поліцейських поставило Сполучені Штати в тяжке становище, в якому вони не були з 1960-х років. «Останні десять років спостерігалось різке зниження злочинності, а сьогодні, за короткий проміжок часу ми бачимо, що всі ці досягнення зведені нанівець», - підсумовував Макдоннелл [24, с. 74].

За такий стан справ афроамериканська спільнота має подякувати саме організаторам руху «Black Lives Matter». Але в такому розвитку подій $є$ вина й частини американських політиків та провідних 3MI, які активно підтримували штучний дискурс про інституційний расизм. Так, наприклад, журналісти «The Washington Post» в 2015 році писали: «Через рік після вбивства Майкла Брауна, неозброєні афроамериканці в 7 разів частіше ніж білі гинуть від вогню поліції ... темношкірі чоловіки становили 40 відсотків із 60 неозброєних людей, яких застрелила поліція. Хоча темношкірі чоловіки складають лише 6 відсотків населення США» [28]. Саме тому, на думку журналістів, активісти BLM настільки невдоволені діяльністю поліції. Але у статті чомусь не враховували іншу статистику. 3987 людей застрелених в 2015 році поліцією, разом 336 неозброєними темношкірими чоловіками було вбито й 31 неозброєного білого чоловіка[24, с. 80]. Журналісти чомусь не зазначили, що з 2005 по 2014 рік 40\% вбивць поліцейських були афрроамериканцями [24, с. 79]. Не звернули увагу й на те, що поліцейські не завжди використовували зброю проти людей завчасно. Так, 5 вбитих афрроамериканців, зазначених як "неозброєні», намагалися забрати зброю у поліцейських або били поліцейських за допомогою відібраного в них під час сутичок спорядження. Ще двоє афроамериканців були вбиті внаслідок рикошету куль, під час виправданої стрільби поліцейськими по справжнім злочинцям [24, с. 81].

Створенням штучного дискурсу навколо розпалювання теми расизму , можна назвати заяву Голови міської ради Нью-Йорка від Демократичної партії США Меліси Марк-Віверіто щодо рішення Великого журі присяжних по справі Еріка Гарнера в 2014 році. Вона назвала рішення не висувати звинувачень поліцейським «страшенно невтішним результатом», що «суперечить подіям, які призвели до смерті Еріка Гарнера» [5]. Така ж реакція на рішення присяжних була й у мера Нью-Йорка, також обраного від Демократичної партії, Біла Де Блазіо:«Люди кажуть:«Життя темношкірих має значення». Це має бути очевидним, однак наша історія вимагає, щоб люди казали «Black Lives Matter». Не роки і не десятки років расизму призвели нас до сьогоднішніх подій, а століття расизму» [24, с. 47]. Крім того, Де Блазіо додав, що він кожну ніч переживає про небезпеки, 3 якими може зустрітися його син, який $є$ мулатом, «зі сторони офіцерів поліції, яким в першу чергу платять за те, щоб вони його захищали» [24, с. 47-48].

Такі заяви та обвинувачення в бік поліції не могли не викликати обурення серед правоохоронців, та ще й після детального розслідування, яке не виявило жодних порушень чи расистських дій $з$ їх сторони. Голова поліцейської профспілки Нью-Йорка, у відповідь на ці заяви, поширив інструкцію, яка дозволяла поліцейським вимагати, щоб мер не відвідував їх похоронів, у разі, якщо вони були вбиті під час виконання службових обов'язків [24, с. 48]. Але найстрашніше те, що після заяв Нью-Йоркських політиків були навмисно вбиті поліцейські, а Сполучені Штати накрила хвиля вбивств на расовому тлі.

Висновки. Громадсько-політичний рух «Black Lives Matter» впродовж своєї медійної та протестної діяльності спричинив величезні погроми та зростання насилля в Сполучених Штатах. Внаслідок безпідставної критики правоохоронних та судових органів США загальний рівень злочинності виріс в рази. I найбільше від цього постраждали саме спільноти афpроамериканців. Організатори BLM маніпулювали фактами щодо причин смерті афроамериканців від вогню поліції. Всі розслідування, які відбувалися під пильним контролем громадськості, підтвердили неупередженість та законність дій правоохоронців. Криміналістична статистика від державних та неурядових установ США доводить, що найбільше афрроамериканщів гине не від вогню поліції, а від злочинності. Найбільше афроамериканців вбивають злочинщі, які самі належать до афроамериканської спільноти. Звинувачення державних органів США та білих громадян в інституційному расизмі виявилися абсолютно безпідставними.

Всі щі фракти доводять, що діяльність громадсько-політичного руху «Black Lives Matter» спричинила тільки збільшення смертності афрроамериканців в США. Організатори та активісти руху замість об'єктивного дослідження та з'ясування справжніх причин високої смертності серед афрроамериканців, займалися власною політичною діяльністю. Частина політиків та провідних ЗМІ також роками докладали зусиль для поширення штучного дискурсу про інституційний расизм, замість того, щоб насправді допомогти подолати високий рівень злочинності та смертності в афрроамериканській громаді. Расистський дискурс продовжують використовувати в США для досягнення політичних девідентів окремі групи впливу. А розплачуватися за це доводиться звичайним громадянам і особливо афрроамерканській спільноті.

\section{Список літератури:}

1. Скрипченко I.В. Громадсько-політичний рух «Black Lives Matter»: уявне та реальне. Політологічний вісник. 2020. Вип. 84. С. 218-227.

2. About Black Lives Matter. Black Lives Matter (electronic website). URL: https://blacklivesmatter.com/about/ (дата звернення: 16.02.2021). 
3. Bennett, D. \& Berman, R. No Indictment. The Atlantic (electronic journal). 2014. URL: https://www.theatlantic.com/ national/archive/2014/11/ferguson-verdict-grand-jury/383130/ (дата звернення: 16.02.2021).

4. Black Homicide Victimization in the United States: An Analysis of 2015 Homicide Data. Violence Policy Center. 2018. P. 1-11.

5. Celona, L., Conley K. \& Golding B. Cop cleared in chokehold death of Eric Garner. New York Post (electronic journal). 2014. URL: https://nypost.com/2014/12/03/cop-cleared-in-eric-garner-chokehold-death/ (дата звернення: 16.02.2021).

6. Celona, L., Cohen, S., Schram, J., Jamieson, A. \& Italiano, L. Gunman executes 2 NYPD cops in Garner 'revenge'. New York Post (electronic journal). 2014. URL: https://nypost.com/2014/12/20/2-nypd-cops-shot-execution-stylein-brooklyn/ (дата звернення: 16.02.2021).

7. Clayton, D.M. Black Lives Matter and the Civil Rights Movement: A Comparative Analysis of Two Social Movements in the United States. Journal of Black Studies. 2018. Vol. 49. № 5. P. 1-33.

8. Crime in the United States, 2015. Federal Bureau of Investigation (electronic website). 2016. URL: https://ucr.fbi.gov/ crime-in-the-u.s/2015/crime-in-the-u.s.-2015/offenses-known-to-law-enforcement/expanded-homicide (дата звернення: 16.02.2021)

9. Crime in the United States, 2000. Federal Bureau of Investigation (electronic website). 2001. URL: https://archives.fbi.gov/archives/news/pressrel/press-releases/crime-in-the-united-states-2000\#: :text=The \%20violent\%20crime\%20rate\%20for,percent\%20from\%20the\%201991\%20rate (дата звернення: 16.02.2021).

10. Cullors, P. \& Moore, D. L. 5 ways to never forget Ferguson - and deliver real justice for Michael Brown. The Guardian (electronic journal). 2014. URL: https://www.theguardian.com/commentisfree/2014/sep/04/neverforget-ferguson-justice-for-michael-brown (дата звернення: 16.02.2021).

11. Cullors, P. \& Moore, D. L. Ferguson protests to \#FergusonNext: 5 paths to progress, after non-indictment. The Guardian (electronic journal). 2014. URL: https://www.theguardian.com/commentisfree/2014/nov/24/ ferguson-protests-progress-non-indictment-grand-jury (дата звернення: 16.02.2021).

12. Day, E. \#BlackLivesMatter: the birth of a new civil rights movement. The Guardian (electronic journal). 2015. URL: https://www.theguardian.com/world/2015/jul/19/blacklivesmatter-birth-civil-rights-movement (дата звернення: 16.02.2021).

13. Death rates for homicide, by sex, race, Hispanic origin, and age: United States, selected years 1950-2014. Centers for Disease Control and Prevention (electronic website). 2015. URL: https://www.cdc.gov/nchs/data/hus/2015/029.pdf (дата звернення: 16.02.2021).

14. Death rates for homicide, by sex, race, Hispanic origin, and age: United States, selected years 1950-2016. Centers for Disease Control and Prevention (electronic website). 2017. URL: https://www.cdc.gov/nchs/data/hus/2017/029.pdf (дата звернення: 16.02.2021).

15. Elder, L. The truth about cops killing blacks. WorldnetDaily (electronic journal). 2016. URL: https://www.wnd.com/ 2016/07/the-truth-about-cops-killing-blacks/\#LWc1WAI0IYWi4UVq.99 (дата звернення: 16.02.2021).

16. FBI Releases 2015 Crime Statistics. Federal Bureau of Investigation (electronic website). 2016. URL: https://www.fbi.gov/news/pressrel/press-releases/fbi-releases-2015-crime-statistics\#: :text=The\%202015\% 20statistics\%20show\%20the,crime\%20rate\%20declined\%203.4\%20percent (дата звернення: 16.02.2021).

17. Feis, A., Sauchelli, D., Celona, L. \& Perez, C. NYPD cops attacked during 'peaceful' protest. New York Post (electronic journal). 2014. URL: https://nypost.com/2014/12/14/nypd-lieutenants-attacked-during-peacefulprotest/ (дата звернення: 16.02.2021).

18. Ferguson on fire. New York Post (electronic journal). 2014. URL: https://nypost.com/2014/11/25/ferguson-on-fire/ (дата звернення: 16.02.2021).

19. Goodwin, M. These are no looter-day saints. New York Post (electronic journal). 2014. URL: https://nypost.com/2014/11/26/ these-are-no-looter-day-saints/ (дата звернення: 16.02.2021).

20. Janos, A., MacMillan, T., Jackson, J. \& Shallwani, P. 300 Arrests After 2 Days of Eric Garner Protests, More Demonstrations Planned. The Wall Street Journal (electronic journal). 2014. URL: https://www.wsj.com/articles/ more-than-200-arrested-in-second-night-of-new-york-city-protests-1417792930 (дата звернення: 16.02.2021).

21. Jones-Eversley, S.D., Rice II, J., Adedoyin, A.C. \& James-Townes, L. Premature Deaths of Young Black Males in the United States. Journal of Black Studies. 2020. Vol. 51. № 3. P. 251-272.

22. Justice in Ferguson. National Review (electronic journal). 2014. URL: https://www.nationalreview.com/2014/11/ justice-ferguson-editors/?itm_source=parsely-api (дата звернення: 16.02.2021).

23. Lovelace, R. Ferguson Protesters Respond to Grand Jury Decision with Gunshots, Destruction, Looting. National Review (electronic journal). 2014. URL: https://www.nationalreview.com/corner/ferguson-protesters-respondgrand-jury-decision-gunshots-destruction-looting-ryan/ (дата звернення: 16.02.2021).

24. Mac Donald, H. The War on Cops: How the New Attack on Law and Order Makes Everyone Less Safe. New York: Encounter Books, 2016. 269 p.

25. Race, Ethnicity, and Sex of Victim by Race, Ethnicity, and Sex of Offender, 2015. Federal Bureau of Investigation (electronic website). 2016. URL: https://ucr.fbi.gov/crime-in-the-u.s/2015/crime-in-the-u.s.-2015/tables/expanded_homicide_data table_6_murder_race_and_sex_of vicitm_by_race_and_sex_of_offender_2015.xls (дата звернення: 16.02.2021).

26. St. Louis-bound flights rerouted amid Ferguson protests. New York Post (electronic journal). 2014. URL: https://nypost.com/2014/11/25/st-louis-bound-flights-rerouted-amid-ferguson-protests/ (дата звернення: 16.02.2021).

27. Salter, J. Ferguson: 5 years later, racial tension lingers nationally. Associated Press (electronic journal). 2019. URL: https://apnews.com/article/dd31d221489e40989f61908a59c685bf (дата звернення: 16.02.2021).

28. Somashekhar, S., Lowery, W., Alexander, K.L., Kindy, K. \& Tate, J. Black and unarmed. The Washington Post (electronic journal). 2015. URL: http://www.washingtonpost.com/sf/national/2015/08/08/black-and-unarmed/ \&prev=search\&pto=aue (дата звернення: 16.02.2021).

29. Video Shows NYC Protesters Chanting for "Dead Cops". NBC 4 New York (electronic website). 2014. URL: https://www.nbcnewyork.com/news/local/eric-garner-manhattan-dead-cops-video-millions-march-protest/ 2015303/ (дата звернення: 16.02.2021).

\section{References:}

1. Skrypchenko, I. (2020) Hromadsko-politychnyi rukh «Black Lives Matter»: uiavne ta realne [Black Lives Matter as a Political and Social Movement: Imagination and Reality]. Politolohichnyi visnyk, vol. 84, pp. 218-227. 
2. About Black Lives Matter. Black Lives Matter (electronic website). Available at: https://blacklivesmatter.com/ about/ (accessed 16 February 2021).

3. Bennett, D. \& Berman, R. (2014) No Indictment. The Atlantic (electronic journal). Available at: https://www.theatlantic.com/national/archive/2014/11/ferguson-verdict-grand-jury/383130/ (accessed 16 February 2021).

4. Black Homicide Victimization in the United States: An Analysis of 2015 Homicide Data (2018) Violence Policy Center, pp. 1-11.

5. Celona, L., Conley K. \& Golding B. (2014) Cop cleared in chokehold death of Eric Garner. New York Post (electronic journal). Available at: https://nypost.com/2014/12/03/cop-cleared-in-eric-garner-chokehold-death/ (accessed 16 February 2021).

6. Celona, L., Cohen, S., Schram, J., Jamieson, A. \& Italiano, L. (2014) Gunman executes 2 NYPD cops in Garner 'revenge'. New York Post (electronic journal). Available at: https://nypost.com/2014/12/20/2-nypd-cops-shotexecution-style-in-brooklyn/ (accessed 16 February 2021).

7. Clayton, D.M. (2018) Black Lives Matter and the Civil Rights Movement: A Comparative Analysis of Two Social Movements in the United States. Journal of Black Studies. Vol. 49. №5. P. 1-33.

8. Crime in the United States, 2000. (2001). Federal Bureau of Investigation (electronic website). Available at: https://archives.fbi.gov/archives/news/pressrel/press-releases/crime-in-the-united-states-2000\#: :text=The\%20 violent\%20crime\%20rate\%20for,percent\%20from\%20the\%201991\%20rate (accessed 16 February 2021).

9. Crime in the United States, 2015. (2016) Federal Bureau of Investigation (electronic website). Available at: https://ucr.fbi.gov/crime-in-the-u.s/2015/crime-in-the-u.s.-2015/offenses-known-to-law-enforcement/expandedhomicide (accessed 16 February 2021).

10. Cullors, P. \& Moore, D. L. (2014) 5 ways to never forget Ferguson - and deliver real justice for Michael Brown. The Guardian (electronic journal). Available at: https://www.theguardian.com/commentisfree/2014/sep/04/neverforget-ferguson-justice-for-michael-brown (accessed 16 February 2021).

11. Cullors, P. \& Moore, D. L. (2014) Ferguson protests to \#FergusonNext: 5 paths to progress, after non-indictment. The Guardian (electronic journal). Available at: https://www.theguardian.com/commentisfree/2014/nov/24/ ferguson-protests-progress-non-indictment-grand-jury (accessed 16 February 2021).

12. Day, E. (2015) \#BlackLivesMatter: the birth of a new civil rights movement. The Guardian (electronic journal). Available at: https://www.theguardian.com/world/2015/jul/19/blacklivesmatter-birth-civil-rights-movement (accessed 16 February 2021).

13. Death rates for homicide, by sex, race, Hispanic origin, and age: United States, selected years 1950-2014 (2015) Centers for Disease Control and Prevention (electronic website). Available at: https://www.cdc.gov/nchs/data/ hus/2015/029.pdf (accessed 16 February 2021).

14. Death rates for homicide, by sex, race, Hispanic origin, and age: United States, selected years 1950-2016 (2017) Centers for Disease Control and Prevention (electronic website). Available at: https://www.cdc.gov/nchs/data/ hus/2017/029.pdf (accessed 16 February 2021).

15. Elder, L. (2016) The truth about cops killing blacks. WorldnetDaily (electronic journal). Available at: https://www.wnd.com/2016/07/the-truth-about-cops-killing-blacks/\#LWc1WAI0IYWi4UVq.99 (accessed 16 February 2021).

16. FBI Releases 2015 Crime Statistics (2016) Federal Bureau of Investigation (electronic website). Available at: https://www.fbi.gov/news/pressrel/press-releases/fbi-releases-2015-crime-statistics\#: :text=The\%202015\%20 statistics\%20show\%20the,crime\%20rate\%20declined\%203.4\%20percent (accessed 16 February 2021).

17. Feis, A., Sauchelli, D., Celona, L. \& Perez, C. (2014). NYPD cops attacked during 'peaceful' protest. New York Post (electronic journal). Available at: https://nypost.com/2014/12/14/nypd-lieutenants-attacked-during-peacefulprotest/ (accessed 16 February 2021).

18. Ferguson on fire (2014) New York Post (electronic journal). Available at: https://nypost.com/2014/11/25/fergusonon-fire/ (accessed 16 February 2021).

19. Goodwin, M. (2014) These are no looter-day saints. New York Post (electronic journal). Available at: https://nypost.com/ 2014/11/26/these-are-no-looter-day-saints/ (accessed 16 February 2021).

20. Janos, A., MacMillan, T., Jackson, J. \& Shallwani, P. (2014) 300 Arrests After 2 Days of Eric Garner Protests, More Demonstrations Planned. The Wall Street Journal (electronic journal). Available at: https://www.wsj.com/articles/ more-than-200-arrested-in-second-night-of-new-york-city-protests-1417792930 (accessed 16 February 2021).

21. Jones-Eversley, S.D., Rice II, J., Adedoyin, A.C. \& James-Townes, L. (2020) Premature Deaths of Young Black Males in the United States. Journal of Black Studies, vol. 51, no. 3, pp. 251-272.

22. Justice in Ferguson (2014) National Review (electronic journal). Available at: https://www.nationalreview.com/2014/11/ justice-ferguson-editors/?itm_source=parsely-api (accessed 16 February 2021).

23. Lovelace, R. (2014). Ferguson Protesters Respond to Grand Jury Decision with Gunshots, Destruction, Looting. National Review (electronic journal). Available at: https://www.nationalreview.com/corner/ferguson-protestersrespond-grand-jury-decision-gunshots-destruction-looting-ryan/ (accessed 16 February 2021).

24. Mac Donald, H. (2016). The War on Cops: How the New Attack on Law and Order Makes Everyone Less Safe. New York: Encounter Books, 269 p.

25. Race, Ethnicity, and Sex of Victim by Race, Ethnicity, and Sex of Offender, 2015 (2016) Federal Bureau of Investigation (electronic website). Available at: https://ucr.fbi.gov/crime-in-the-u.s/2015/crime-in-the-u.s.-2015/ tables/expanded_homicide_data_table_6_murder_race_and_sex_of_vicitm_by_race_and_sex_of_offender_2015.xls (accessed 16 February 2021).

26. St. Louis-bound flights rerouted amid Ferguson protests (2014) New York Post (electronic journal). Available at: https://nypost.com/2014/11/25/st-louis-bound-flights-rerouted-amid-ferguson-protests/ (accessed 16 February 2021).

27. Salter, J. (2019). Ferguson: 5 years later, racial tension lingers nationally. Associated Press (electronic journal). Available at: https://apnews.com/article/dd31d221489e40989f61908a59c685bf (accessed 16 February 2021).

28. Somashekhar, S., Lowery, W., Alexander, K.L., Kindy, K. \& Tate, J. (2015). Black and unarmed. The Washington Post (electronic journal). Available at: http://www.washingtonpost.com/sf/national/2015/08/08/black-and-unarmed/ $\&$ prev $=$ search\&pto=aue (accessed 16 February 2021).

29. Video Shows NYC Protesters Chanting for "Dead Cops" (2014) NBC 4 New York (electronic website). Available at: https://www.nbcnewyork.com/news/local/eric-garner-manhattan-dead-cops-video-millions-marchprotest/2015303/ (accessed 16 February 2021). 